\title{
THE LOCATION AND TIMING OF DEEP SLAB AVALANCHES
}

\author{
By Charles C. Bradley \\ (Department of Earth Sciences, Montana State University, Bozeman, Montana 597I5, \\ U.S.A.)
}

Abstract. Winter observations in the northern Rocky Mountains of Montana show two periods during which one may expect a collapsing snowpack and accompanying avalanches: ( $\mathrm{I}$ ) shaded and sheltered areas: December-February; (2) sunny and exposed areas: March-May. These periods appear to be linked in part to the cyclic rise and fall of strength in the basal snow layer. It is suggested that sheltered slopes are often about a half-cycle ahead of sunny slopes because sheltered slopes tend to retain the early snows which later become the critically weak basal layer on these slopes.

RÉsumé. La localisation dans l'espace et le temps des avalanches de plaques épaisses. Les observations faites en hiver dans les Rocky Mountains du nord de Montana ont permis de constater qu'il existe deux périodes au cours desquelles on peut s'attendre à un effondrement d'amas de neige accompagné d'avalanches: (I) lieux ombragés et abrités: décembre-février; (2) lieux ensoleillés et découverts: mars-mai. Ces périodes semblent être liées en partie à l'augmentation cyclique et à la perte de force de la couche de base de la neige. Il est suggéré que les pentes abritées ont souvent un demi-cycle d'avance sur les pentes ensoleillées, parce que les pentes abritées tendent à retenir les premières neiges qui, plus tard, forment la couche critiquement faible sur ces pentes.

Zusammenfassung. Vorkommen und Ablaüf tiefer Schneebrett-Lawinen. Winterbeobachtungen in den nördlichen Rocky Mountains von Montana lassen 2 Perioden erkennen, in denen man zusammenbrechende Schneeschichten und die sie begleitenden Lawinen erwarten kann: (1) schattige und geschützte Flächen: Dezember-Februar; (2) sonnige und ungeschützte Flächen: März-Mai. Diese Perioden scheinen zum Teil mit dem zyklischen $\mathrm{Zu}$ - und Abnehmen der Festigkeit in der untersten Schneeschicht zusammenzuhängen. Es wird angenommen, dass geschützte Abhänge oft den sonnigen Abhängen um ungefähr einen halben Zyklus veraus sind, da geschützte Abhänge dazu neigen, den frühøn Schnee zu bewahren, der später zur kritisch schwachen Grundschicht auf diesen Abhängen wird.

\section{INTRODUCTION}

Deep slab avalanches are here defined as those snow avalanches initiated by the sudden collapse of the basal layers of the snowpack under the overlying snow load. As such, these avalanches would constitute a genetic subtype under the Swiss classification "ground slab avalanche" (Quervain, I966) or the U.S. Forest Service "climax avalanche" ([U.S. Dept. of Agriculture. Forest Service], I96I).

Two conditions at the base of the snowpack are worthy of note: (I) A poorly sintered, low-density basal layer which frequently displays subhedral to euhedral depth hoar crystals; (2) A pre-collapse basal strength to load ratio $(\mathrm{S} / \mathrm{L})$ of $<4$ where strength is measured with the snow resistograph and load is taken with the Mt Rose snow sampler (Bradley and Bowles, I 967$)$.

The resistograph is an instrument which plots a profile of snow strength as a function of depth in the pack. To obtain $\mathrm{S} / \mathrm{L}$, a resistogram is first taken to identify the position and strength of the weakest layer near the base. The Mt Rose sampler is then used to obtain a measure of the snow load overlying that weak layer.

In this paper $\mathrm{S} / \mathrm{L}$ is considered to be a general index of systemic strength. A collapsing snowpack, deep slab avalanches and $\mathrm{S} / \mathrm{L}<4$ are all considered to be indices of critical systemic weakness.

Deep slab avalanches, though common in the northern Rocky Mountains of Montana, are by no means a universal winter phenomenon. In my i 9 winters of observation in the Bozeman area, there have only been four I would class as years of widespread deep slab avalanches. On the other hand, it is also true that each year has revealed some broad areas of slope which have developed at some moment the general critical weakness leading to collapse and avalanche. These same slopes in other years might remain completely stable for the whole season or might achieve so little synchronization of weak zones that general failure never develops. 
This paper is concerned with two factors which help bring about synchronous basal weakness and collapse over broad areas. These two factors are the systemic strength cycle and the location of the first permanent snows of winter.

\section{Systemic STRENGTH CYCLES}

Observations in the Bridger Range of Montana (Bradley, I966; Bradley and Bowles, 1967) showed the possibility of estimating the susceptibility of the snowpack to collapse by obtaining the strength to load ratio at the base of the pack. In addition, it was shown that while this ratio generally decreases as the season advances, it is also subject to significant oscillations, probably as the result of the interplay between metamorphic weakening and load consolidation. Cyclic weakness of basal snow was also noted by Roch (ig66).

Metamorphic weakening accompanied by accumulating snow load ultimately may lead to compressional failure of the basal layer. This may be sudden and accompanied by snowpack fracture. More often, however, the pack apparently subsides plastically. In either case, the subsidence brings about a period of stability and basal consolidation before metamorphism

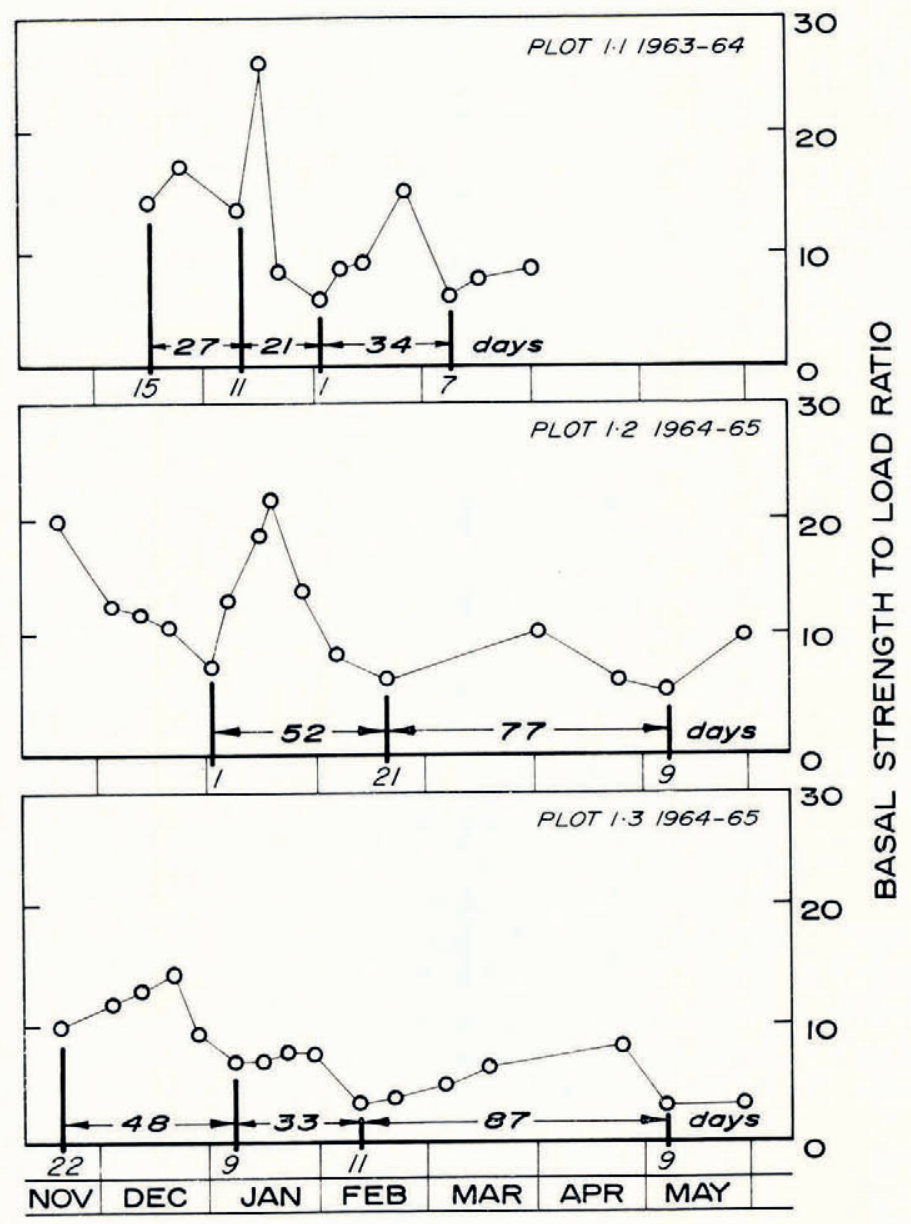

Fig. I. Strength-load ratios at the base of the snowpack in three study areas, plotted against a time base and showing apparent cycles of systemic weakness. 
and further snowfall initiates a new cycle of systemic weakening. The period of this cycle, though highly variable, appears to be about $30-50 \mathrm{~d}$ in the early part of the snow season and lengthens to about $80 \mathrm{~d}$ towards the end of the season (Fig. I). This might be expected because normally the temperature gradient, and hence the rate of basal metamorphism, would decrease as the pack thickens and as summer heat stored in the ground is dissipated.

The fact that these cycles are superimposed on a general decline in the strength to load ratio increases the likelihood of collapsing conditions as the season advances and tends to act against the probability of critical weakness being reached in the early season pack.

\section{Avalanche timing and Slope orientation (Fig. 2)}

In the northern Rockies one peculiarity of deep slab avalanches (and other manifestations of systemic weakness) is their apparent seasonal timing with regard to slope orientation. North-facing and sheltered slopes tend to fail around the month of January with a second but minor peak in May. South-facing slopes show a strong tendency to collapse and avalanche around the month of April.

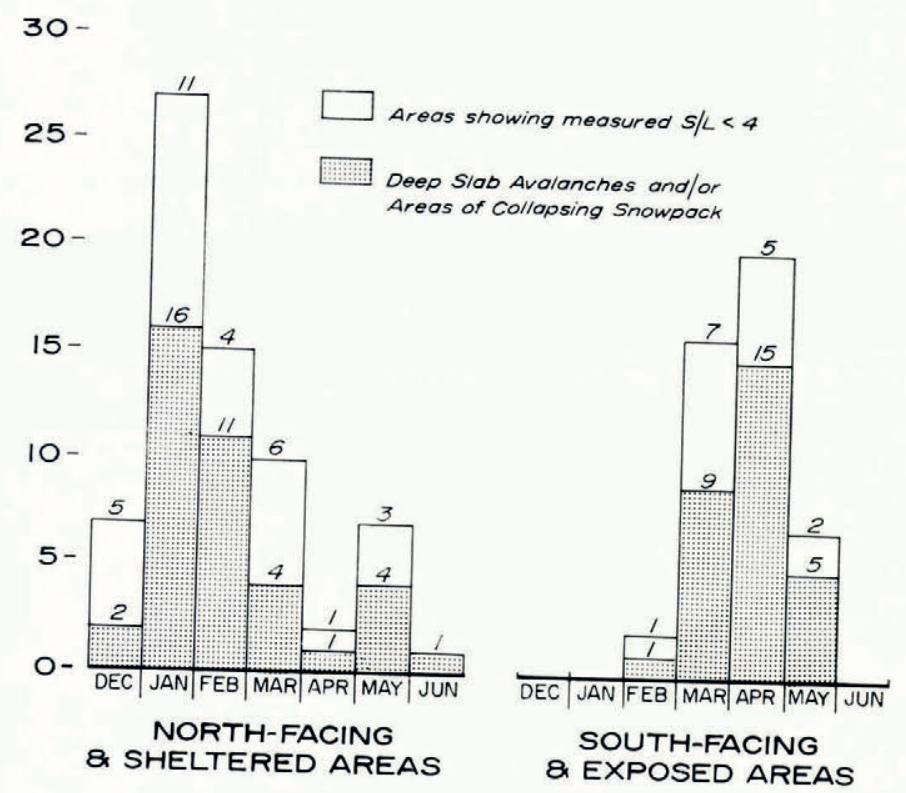

Fig. 2. Seasonal periods of systemic snowpack weakness as related to slope orientation or other protection from insolation.

Figure 2 was compiled from personal notes taken in the ro year period I $959-69$. It contains all observed occurrences of systemic weakness in the mountains around Bozeman, Montana. That is, featured in the bar graphs are all instances of deep slab avalanches, collapsing snowpack and significant areas displaying $\mathrm{S} / \mathrm{L}<4$ in which the date and slope orientation or degree of shelter could be established.

One cannot escape the conclusion that insolation has had an influence on this systematic distribution of weakness periods. Just what the influence consists of is not immediately apparent. The source of weakness lies at the base of the pack well beyond the reach of direct sunlight. Two mechanisms are suggested: (I) The sunlight could lower slab strength during a warm period ([U.S. Dept. of Agriculture. Forest Service], I96I). This would reduce the bridging capacity of the slab and make it more susceptible to failure. Such a process helps 


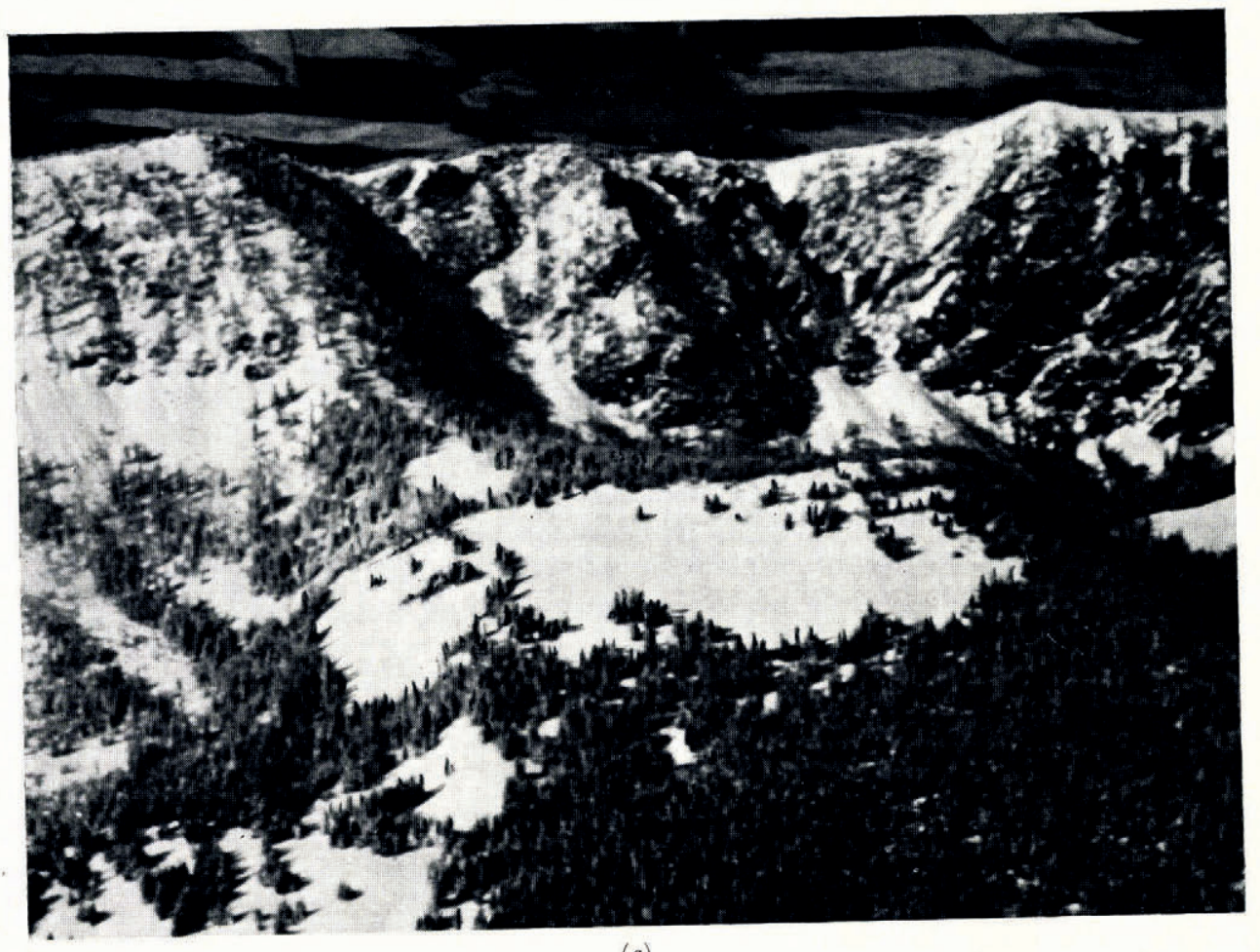

(a)

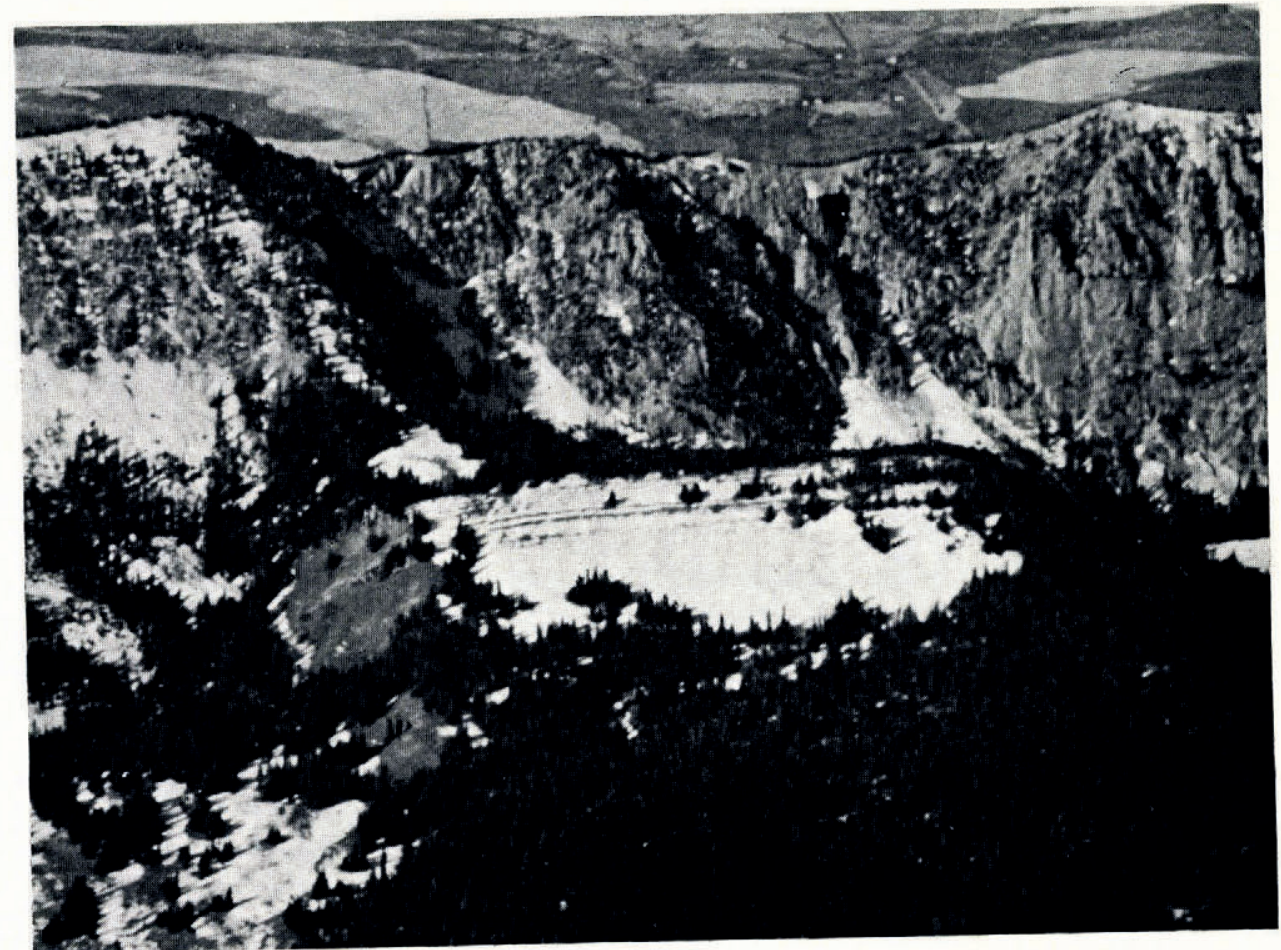

(b)

Fig. 3. Aerial views looking west at the $1967-68$ snow-study plot (central clearing), Bridger Range, Montana, U.S.A. a. Snow cover 15 October 1967 . b. Snow cover 21 October 1967. 
explain the spring avalanches on warm slopes. (2) The susceptibility of north-facing slopes to mid-winter avalanches was noted by Bucher (1946). He attributed this sensitivity to rapid metamorphism of the early snows resulting from a thin snow cover and steep thermal gradient in the pack.

The study reported here was based upon still another mechanism-the idea that the location of the first persistent snows of winter might hold a key to the seasonal distribution of deep slab avalanches. The early snows later become the basal snow and the early snows would best survive on the shaded and sheltered north slopes ([U.S. Dept. of Agriculture. Forest Service], I96r).

\section{Method of Study}

The area selected for study is an open glade on the east slope of the Bridger Range (Figs. 3 and 4 ). The glade is about $300 \mathrm{~m}$ north-south by $180 \mathrm{~m}$ east-west and is divided by a topographic spur which separates a south-east-facing slope from a north-east-facing slope. The plan was to conduct three synoptic studies of the basal strength to load ratio on the area during the course of the winter to see what the patterns might reveal.

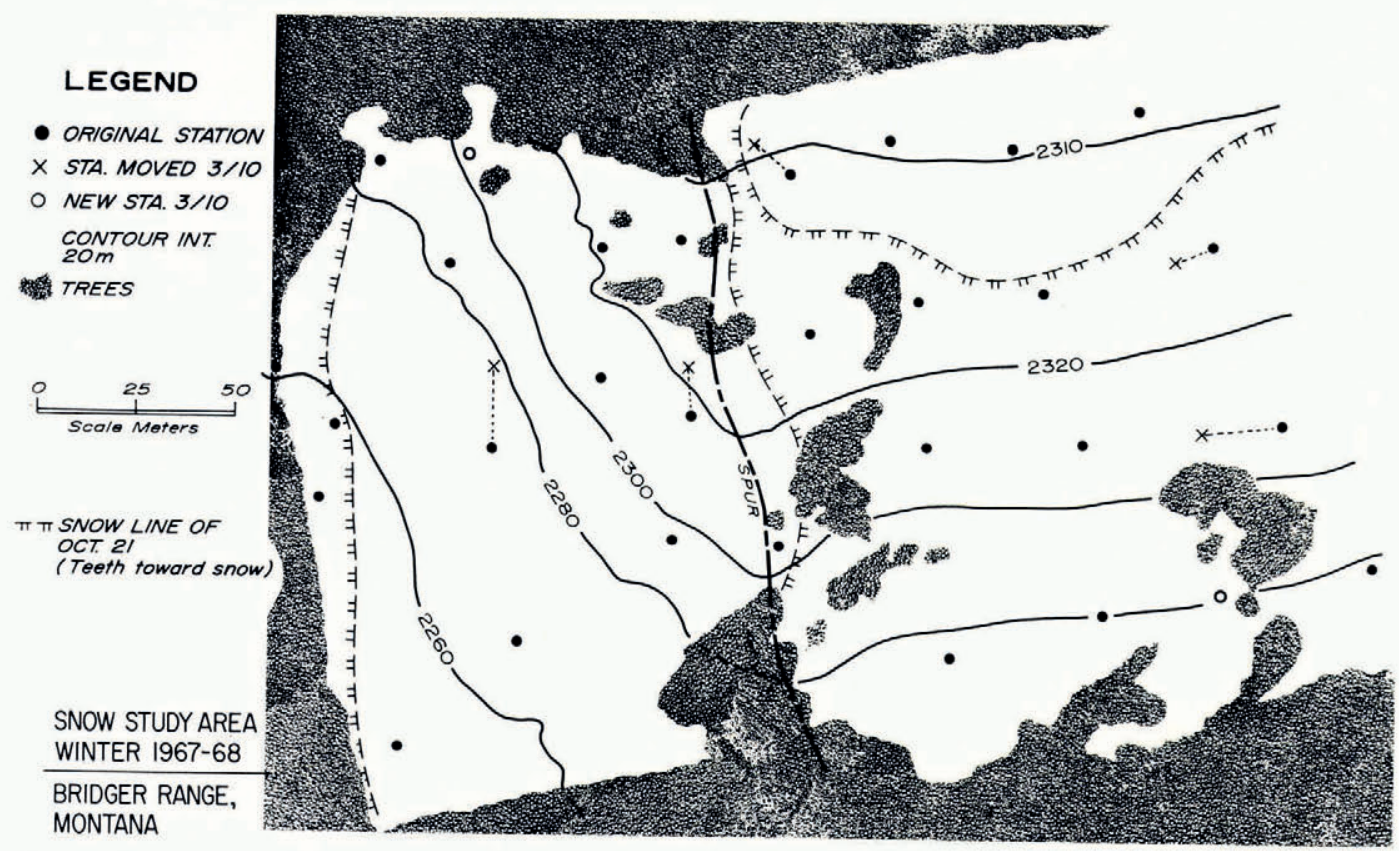
Fig. 4. Topographic base map of 1967-68 study plot, showing location of measuring stations and the position of the late October
snow line.

During October-November I967, aerial photographs of the area were taken weekly to help establish the early snow distribution prior to the permanent winter cover.

Figure 3 a shows the area on I 5 October, shortly after a snowstorm. By 2 I October, shortly before permanent burial, the snow had melted back so that the only significant snow cover (greater than $25 \mathrm{~cm}$ thick) was in the lower part of the north-east-facing slope and in a treesheltered strip at the south edge of the south-east-facing slope (Fig. 3 b). The late October snow line is shown on the base map (Fig. 4). 
To achieve synoptic observations, a network of 27 stations was established in the study plot with pole markers for identification. The positions of these, too, are shown on the base map. On I4 January, io March and ig May, basal strength and load measurements were made at each station using the snow resistograph and Mt Rose snow sampler.

During the first interim period one station was carried away and buried by a small avalanche; four others were buried in the larger-than-expected snowfall. Since we did not have the base map on hand at the time of the March synopsis, the positions of these five stations were re-established by estimate. Later survey showed some errors in the estimated positions but the data seemed consistent and were used. Also, during the March synopsis, two more stations were added, enlarging the total to 29. On the base map, using overlays, isograds of systemic strength (S/L) were drawn for each synoptic period (Figs. 5, 6 and 7 ). Also mapped were the isograds of net gains and losses between each two successive synoptic periods (Figs. 8 and 9 ).

\section{Observations}

From Figures $5^{-9}$ it is quite clear that a general relationship exists between strength patterns and slope orientation.

The spur between the slopes early developed its own narrow ridge of strength. This resulted from the prevailing southerly winds which created a line of well-compacted drifts on the north side of the spur. With increasing depth of snow cover and progressive basal metamorphism this initial effect disappeared.

There was an apparent cyclic rise and fall in the systemic strength of the snowpack with the two slopes being about a half-cycle out of phase. This reinforces the bar-graph pattern of Figure 2. The January synopsis (Fig. 5) shows a large area of systemic weakness $(\mathrm{S} / \mathrm{L}<4)$ on the lower part of the north-east-facing slope. By March (Fig. 6) this had strengthened up while the south slope had become critically weak and had started to settle. In fact, during the synopsis the party experienced sudden collapse of a part of the pack just south of the crest in

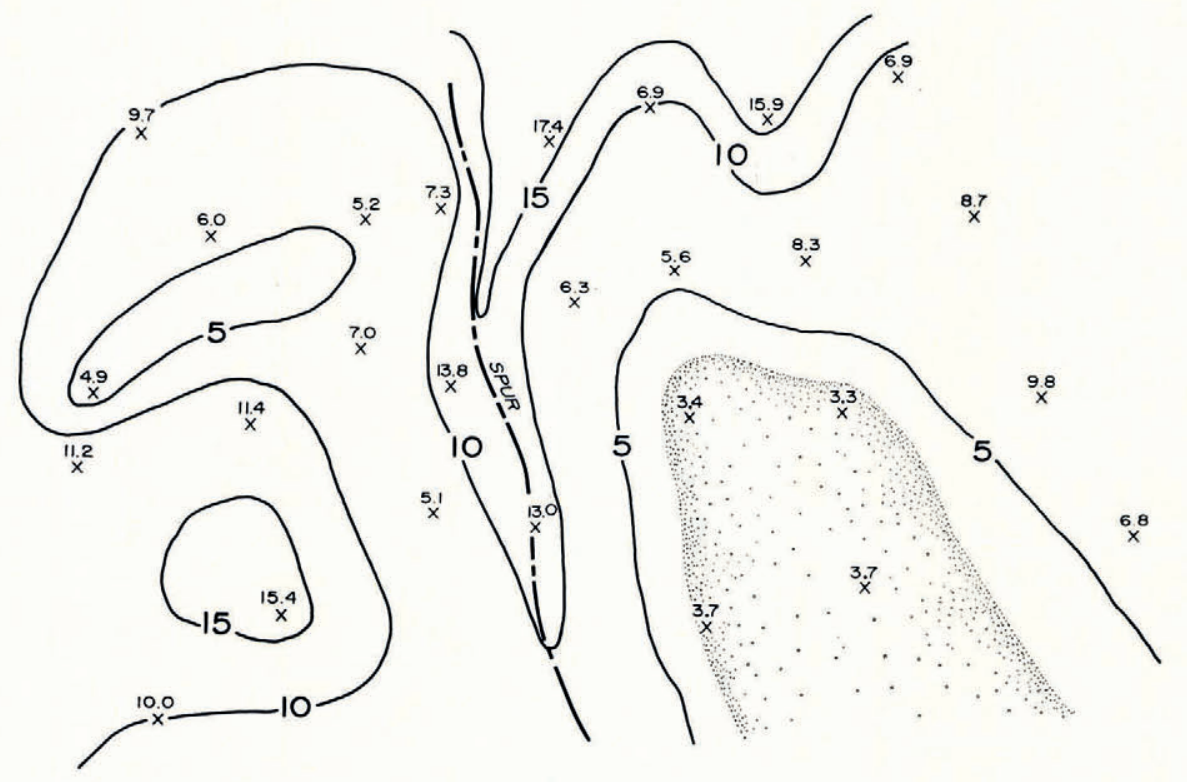

Fig. 5. Overlay from base map showing 14 January 1968 measurements of strength-load ratio at each station and approximate isograds of systemic strength $(S / L)$. Stippled areas have $S / L<4$. 


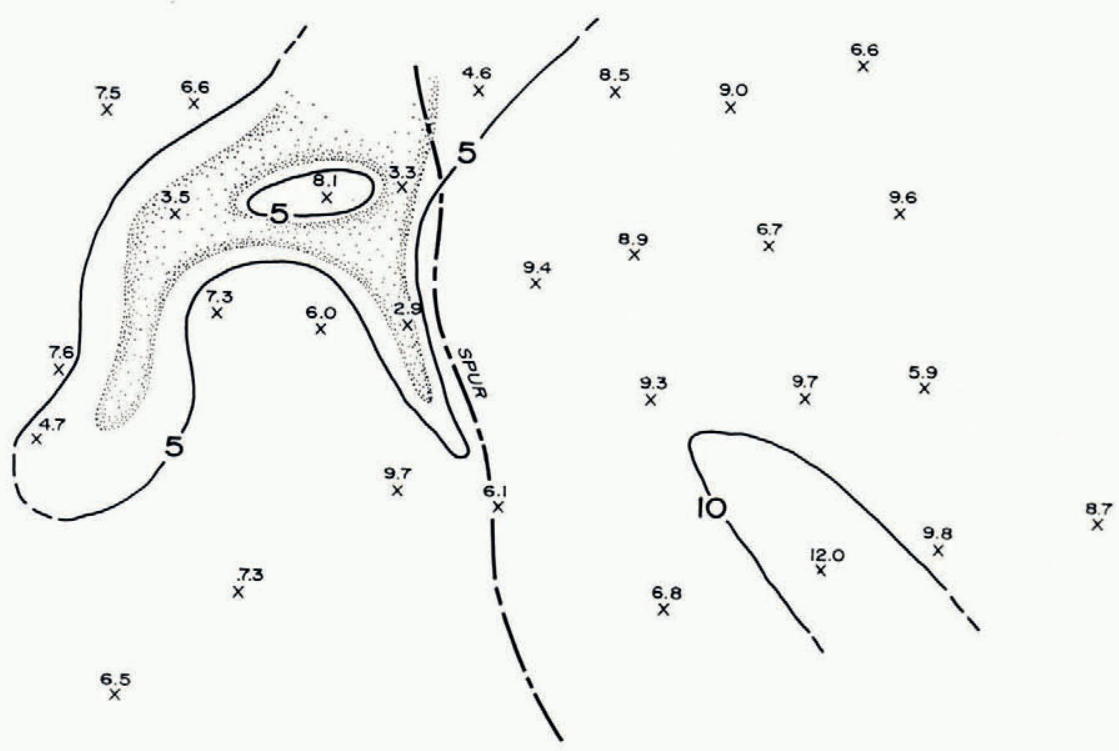

Fig. 6. Overlay similar to Figure 5 for 10 March measurements.

the central part of the map. In the May synopsis, the north slope had once again weakened while the exposed south slope had stabilized. Again, the party experienced collapsing snow, this time in the tree-sheltered zone immediately south of the study area.

Perhaps of most interest is the fact that the lines of zero net change between synoptic periods (Figs. 8 and 9) match quite closely the late October snow line. To illustrate this in more quantitative terms, Figure 8 shows I2 stations on the snow side of the snow line. Of these, nine show a gain in systemic strength, three show a loss with a total average net gain of

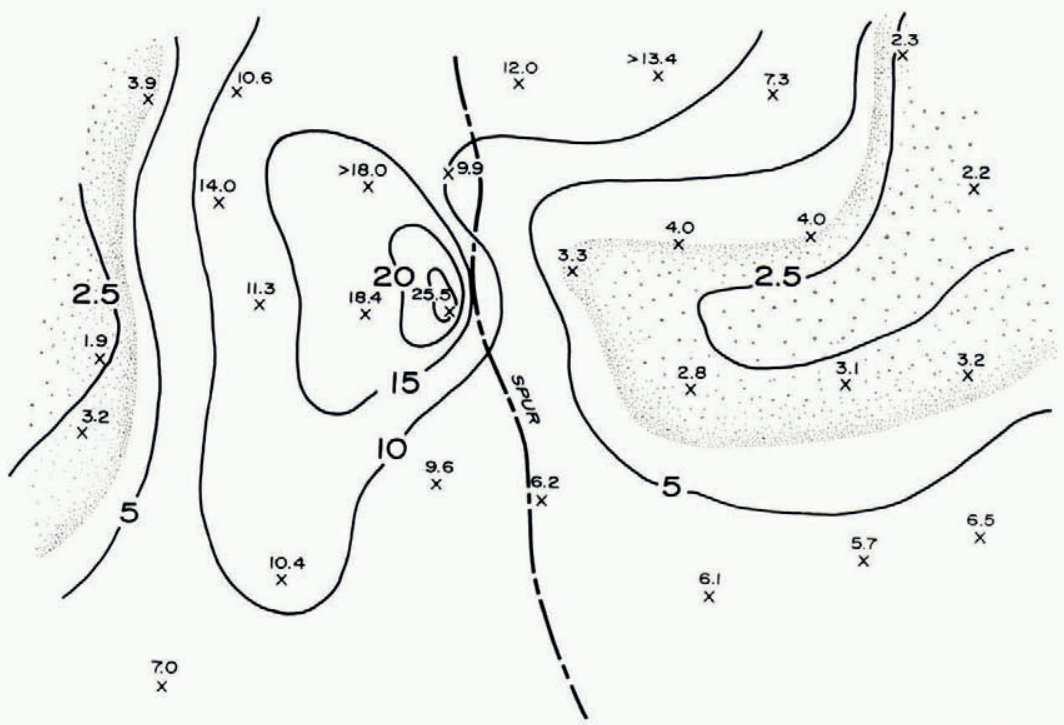

Fig. 7. Overlay for I9 May measurements. 


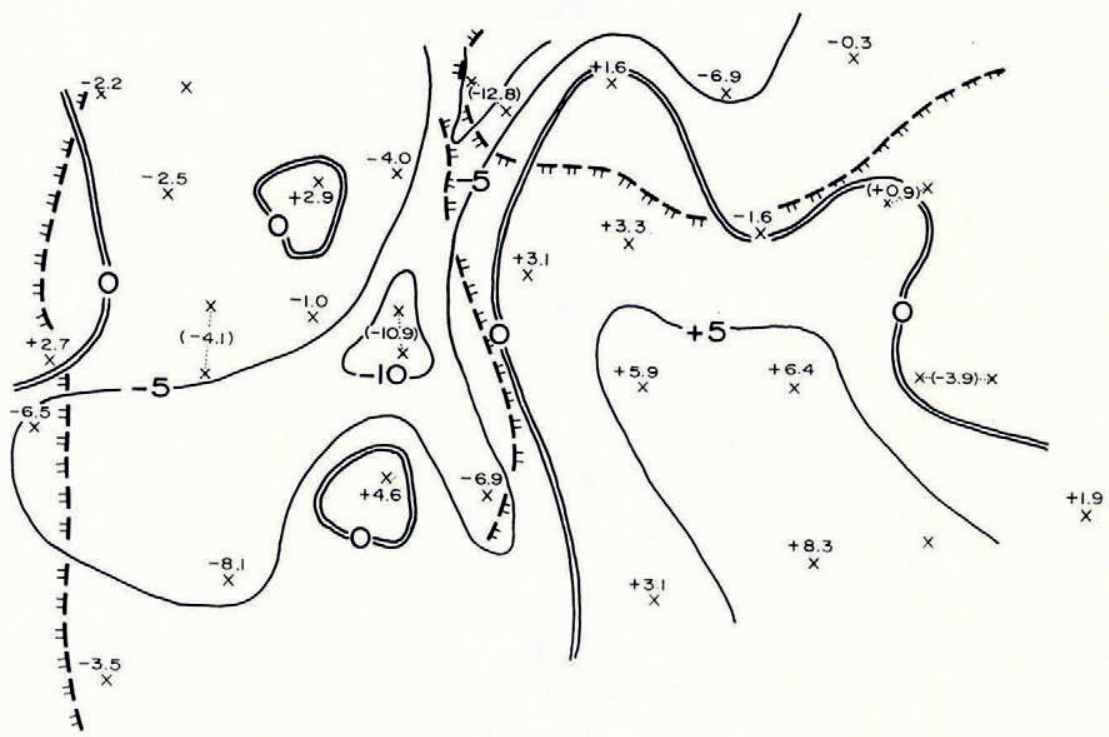

Fig. 8. Overlay from base map showing isograds of net changes in systemic strength $(S \mid L)$ which took place between $I_{4}$ January and 10 March. Also shown is late October snow line (toothed) for comparison with line of zero net change.

2.o per station. Of the 15 stations on the warm side of the line, 12 show a net loss, three show a net gain with a total average net loss of 3.8 per station.

Figure 9 shows all 12 stations on the snow side of the line displaying a loss which averages 4.5 per station. Of the 16 stations on the warm side, 12 show a gain, four show a loss, the average net gain per station being 4.8 .

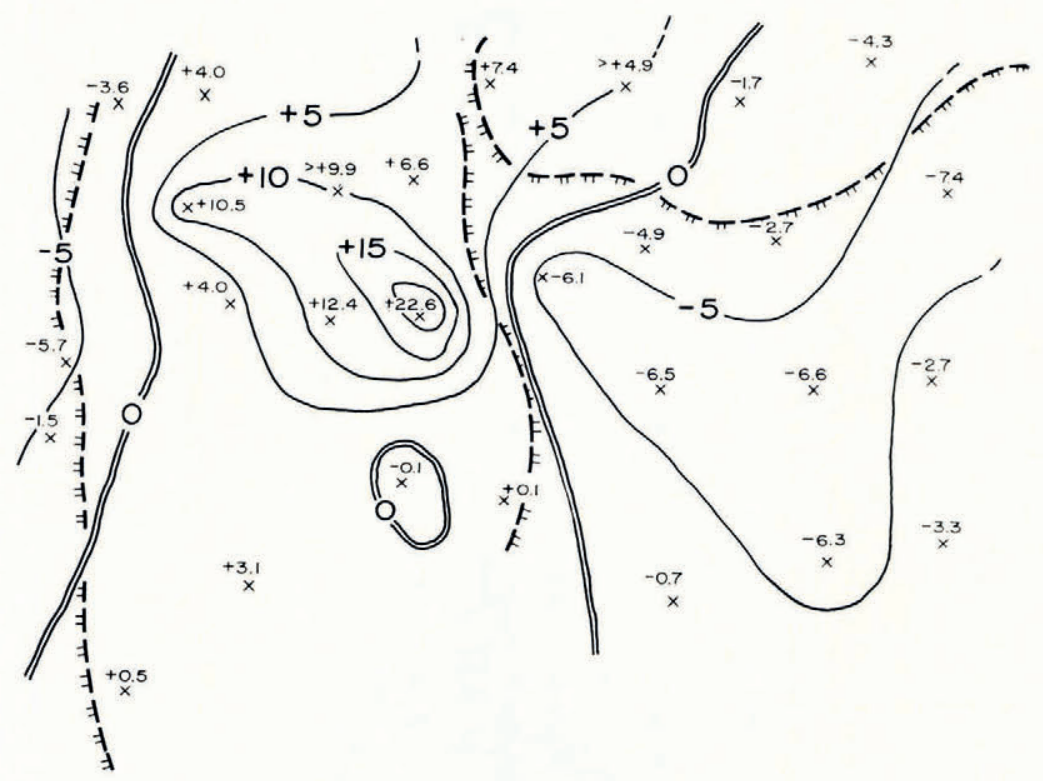

Fig. 9. Overlay similar to Figure 8 for changes between 10 March and 19 May. 
Winter OF I968-69

Before concluding this paper it should be said that an attempt was made to duplicate the I $967-68$ study the following winter. This was a failure. The pattern of weather and snowfall was quite different. The strength of the basal snow rose and fell at each station in a completely non-synchronous manner. However, since synchronous patterns did develop during 1968-69 on some areas not under intensive study, it seemed reasonable to present the results of the $1967-68$ study alone, recognizing that even at best it contains only partial answers to the complex question of what brings about synchronous critical weakness over a large area.

\section{Conclusion}

These studies provide some quantitative information relative to the observed relationship of slope orientation to the seasonal timing of deep slab avalanches.

It seems certain that both the location of the first surviving snow of winter and the cycle of systemic strength play important interlocking roles in the process. That they are not the only factors is apparent from the fact that the snow line and the line of zero net change of strength in this study were, after all, not perfectly matched.

Though somewhat repetitous of earlier work, perhaps it is useful in closing to list an ideal sequence of events which would favor a winter of widespread deep slab avalanches on the January north slope-April south slope pattern discussed in this paper: (I) A warm summer and early autumn; (2) a series of late autumn snowstorms alternating with bright clear cool weather which removes the snow from the south slopes but allows it to accumulate to considerable depth and become thoroughly metamorphosed on the north slopes; (3) low temperatures and rapid accumulation of early winter snow to overload the weakened basal layer on the north slopes more rapidly than it can accommodate by plastic subsidence; (4) warm April weather and heavy wet snowstorms to weaken and overload the snowpack on south slopes; (5) continued heavy wet spring snows and warm weather to weaken and overload the northfacing slopes for a second cycle of collapse and deep slab avalanches in May.

\section{Acknowledgements}

I am grateful to Charles Love, Duain Bowles, Gary Morrison, and my wife for much needed assistance in making the synopses. I am also indebted to John Montagne, Edward LaChapelle and Arlin Super for helpful criticism in the development of the study and the preparation of this paper. This research was financed in part by the National Science Foundation under grants $\mathrm{GP}_{3} 692$ and $\mathrm{GA}_{75} 6$.

\section{MS. received 24 August 1969 and in revised form Io February 1970}

\section{REFERENCES}

Bradley, C. C. 1966. The snow resistograph and slab avalanche investigations. Union de Géodésie et Géophysique Internationale. Association Internationale d'Hydrologie Scientifique. Commission pour la Neige et la Glace. Division Neige Saisonnière et Avalanches. Symposium international sur les aspects scientifiques des avalanches de neige, 5 -10 avril 1965 ,
Davos, Suisse, p. 251-6o.

Bradley, C. C., and Bowles, D. 1967. Strength-load ratio: an index of deep slab avalanche conditions. (In Oura, H., ed. Physics of snow and ice: international conference on low temperature science. . . . 1966. ... Proceedings,
Vol. I, Pt. 2. [Sapporo], Institute of Low Temperature Science Vol. 1, Pt. 2. [Sapporo], Institute of Low Temperature Science, Hokkaido University, p. I 243-53.)

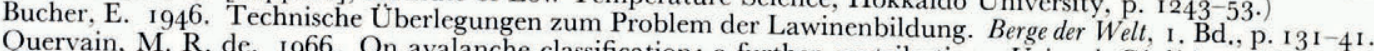

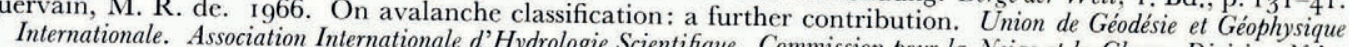
Saisonnière et Avalanches. Symposium internationalo Scientifique. Commission pour la Neige et la Glace. Division Neige Saisonniere et Avalanches. Symposium international sur les aspects scientifiques des avalanches de neige, 5-10 avril 1965 ,
Davos, Suisse, p. 410-17. Internationale d'Hydrologie Scientifique.sistance de la neige. Union de Géodésie et Géophysique Internationale. Association Internationale d'Hydrologie Scientifique. Commission pour la Neige et la Glace. Division Neige Saisonnière et Avalanches. U.S. Dept. of Agriculture. Forest Service. [Washington, D.C.]. [U.S.] Derest Service.] I961. Snow avalanches: a handbook of forecasting and control measures. 